\title{
Through the Lens of Good Language Learners: What Are Their Strategies?
}

\author{
Nurhuda Mohamad Nazri (Corresponding author) \\ Universiti Kuala Lumpur Institute of Medical Science Technology \\ Kajang, Selangor, Malaysia \\ E-mail: nurhuda@unikl.edu.my \\ Melor Md Yunus \\ Faculty of Education, Universiti Kebangsaan Malaysia \\ Bangi, Selangor, Malaysia \\ E-mail: melor@ukm.edu.my \\ Nur Dalila Mohamad Nazri \\ Faculty of Major Languages Studies, Universiti Sains Islam Malaysia \\ Nilai, Negeri Sembilan, Malaysia \\ E-mail: dalila@usim.edu.my
}

Doi:10.7575/aiac.alls.v.7n.1p.195

Received: 29/09/2015

URL: http://dx.doi.org/10.7575/aiac.alls.v.7n.1p.195

Accepted: 09/12/2015

The research is financed by Universiti Kuala Lumpur.

\begin{abstract}
Often times, many English as Second Language (ESL) facilitators speculate why some learners learn faster than other learners. Provided the students were exposed with the same amount of years in the formal education system in Malaysia, the language instructors curious about the variety of performance in the English language among the learners. This study revealed the language learning strategies used by ten successful ESL learners of a private university in Kajang, Selangor, using Oxford's (1990) Strategy Inventory for Language Learning (SILL). The findings indicated that successful language learners are high frequency users of language learning strategies. The total mean of each category showed that metacognitive strategies (Mean=3.964) are among the most frequently used strategies, followed respectively by compensatory (Mean=3.814), cognitive (Mean=3.812), social (Mean=3.700), memory $($ Mean=3.100) and affective strategies (Mean=2.890) found as the least used strategies among successful language learners. Interestingly, the study also identified that successful language learners used more direct strategies compared to indirect strategies. The findings have significant implications for research on language learning strategies for successful language learners and teacher planning in order to promote and boost the use of strategies among the poor language learners.
\end{abstract}

Keywords: language learning strategies, successful learners, English as a Second Language

\section{Introduction}

English has become an essential language and is given high status in Malaysian education system. Almost every issue pertaining to English language teaching and learning in mainstream curriculum has received a great deal of attention ranging from political parties, policy makers, linguists, educators to parents. Either in academia or career, the mastery of English is compulsory in the ever borderless and competitive world today. Undeniably, every student employs different approaches in learning English as a second language. According to Oxford (1990), theory has proven that strategy use yields to the effectiveness in language learning. The explanation for the statement is that the more aware learners are on the strategies they use, the more adept learners will be. Rubin (1975) suggested that if we are well aware of the strategies used by good language learners, we could try to impart and teach these strategies to poorer learners to enhance their language performance. Rubin (1975) also identified a list of approaches of the good language learners, which based on her findings, are enthusiastic and capable to use hints in order to deduce for meaning, employ a variety of methods to converse or learn from conversation, cope with inhibitions, practice the target language, attend to form and meaning and observe both their own and others' speech. These strategies will differ depending on certain variables such as level of the task, age of the learners, learning context and environment, learning styles, socio-economic status of the family and cultural differences. She opined knowledge about good language learners will lessen the gap exists between the good and the poorer learner. In search for an answer to this issue, this present study on strategy use was conducted among ten successful English language learners of a private university in Malaysia. The goal was aimed towards determining the strategies good learners employed as to the ones used the most and least. 


\section{Literature Review}

\subsection{The definitions of Language Learning Strategies}

Language learning strategy has emerged as a field of inquiry in the mid-1970s, when second language acquisition experts began to concentrate on individual variation among learners. The studies on language learning strategies have grown vigorously in the past few decades in ESL context. According to Weinstein \& Rogers (1984), learning strategies were defined as understandings or actions that a learner employs during learning that are intended to affect the encoding process to facilitate the attainment, preservation, and reclamation of new knowledge. Correspondingly, another explanation to describe learning strategies is the steps taken by the learners to facilitate the attainment, storage, recovery, or usage of information (O'Malley et. al, 1985).

Oxford's (1990) classifications of the language learning strategies were agreed by many experts to be the most specific and comprehensive thus far. She defined language learning strategies as "specific actions taken by the learner to make learning easier, faster, more enjoyable, more self-directed, more effective, and more transferable to new situations." (p. 8). Based on her work and others in the language learning strategies field, language learning strategies can be said to have a number of distinctive characteristics. The language learning strategies model of Oxford categorized the strategies into two categories which are direct and indirect. Under direct strategies, she further classified language learning strategies into three broad categories called memory, cognitive, compensation strategies. On the other hand, she has classified metacognitive, affective, and social strategies to be under indirect strategies. Strategies are problem orientated and contribute directly and indirectly to learning. On occasions they are not associated with mental processing or the cognitive functions of the individual, thus rendering them behaviors which can also be either social or affective (Ellis, 1994; Oxford, 1990). Furthermore, they are intentional and usually conscious to the individual, but they may result in outcomes which can be either observed and unobservable (Ellis, 1994; Wenden and Rubin, 1987).

\subsection{The Characteristics of Successful Language Learners}

Rubin (1975), Stern (1975) and Naiman, et al. (1978) discovered the likelihood that great achievement in language learning might be associated to the use of strategies among the successful language learners. Rubin and Thompson (1994) as well as Mohamed Amin (2000) have characterized some broad language learning strategies employed by the successful language learners. According to them, successful language learners always find or even create opportunities to use the target language, make rooms to always practice the language, exploit social means, make effort to convey and get the message across, optimistic and prepared to live with uncertainty, observe their own speech as well as others, solicit language patterns, employ the target language input and make errors work. They also plan and schedule their language learning, read comprehensively and last but not least, they experiment with different learning strategies. In a number of studies, a connection between the effectiveness in the use of learning strategies and language success has been identified. Mohamed Amin Embi et al., (2001) also suggested that good learners were revealed to have a greater use of language learning strategies compared to poor learners.

\section{Method}

\subsection{Respondents}

In this study, ten students were selected to be the respondents through purposive sampling method. Also known as nonprobability sampling technique, this method was chosen to ensure the sample possessed the same characteristic which was good language learners. This method enabled the transparency of the findings thus established the validity of the study. They were all identified as successful language learners in the university based upon their exceptional grades for English paper in Sijil Pelajaran Malaysia (SPM) as well as their outstanding language proficiency observed throughout English classes and tests. Each of the respondents fit to the requirement of the study as they were all ESL learners.

\subsection{Instrumentation}

Oxford's taxonomy was chosen to assess language learning strategies (LLS) in this study. Oxford's Strategy Inventory for Language Learning (SILL) Version 7.0 was used in order to collect information about the topic. The decision to opt for this questionnaire was made on three reasons. Firstly, the questionnaire is perfect to assess language learning strategy used by English as second language (ESL) and English as Foreign Language (EFL) learners with different cultural backgrounds. For instance, Oxford's taxonomy has been widely used among the Arabic, Chinese, Hispanic and Japanese students. (Touba: 1992, Chang: 1990, Green: 1991, Watanabe: 1990). Secondly, the reliability and validity of the questionnaire have been extensively tested and verified (Oxford, 1992). Thirdly, it was estimated that the questionnaire has been broadly used in major studies across the world involving approximately ten thousands language learners (Kaylani, 1996). The inventory comprises of fifty items on which they marked their responses on a Likert scale of 5 points, ranging from 1 for "Never or almost never true of me" to 5 for "Always or almost always true of me." The respondents completed the questionnaire in 25 minutes under the supervision of the researcher.

\subsection{Data Analysis}

To determine the frequency of language learning strategies used, a total of mean score was employed. The rating of frequency employed from the SILL was divided into three major categories of use. Mean of 1.0 to 2.4 was considered as low strategy use, 2.5 to 3.4 were characterized into medium strategy use and mean of 3.5 to 5.0 was regarded as high strategy use. 


\section{Findings}

\subsection{Overall strategy use}

Table 1. Mean Scores and Frequency of Language Learning Strategies Usage

\begin{tabular}{lllc}
\hline Strategy & Mean & Frequency & Rank \\
\hline Metacognitive & 3.964 & High & 1 \\
Compensatory & 3.814 & High & 2 \\
Cognitive & 3.812 & High & 3 \\
Social & 3.700 & High & 4 \\
Memory & 3.100 & Medium & 5 \\
Affective & 2.890 & Medium & 6 \\
\hline Total & 3.547 & & \\
\hline
\end{tabular}

Table 1 illustrates the mean of the overall strategy use was 3.547. This depicts the respondents, whom were successful language learners, were high strategy users. The students were also reported to possess high level in the frequency use for four categories (metacognitive, compensatory, cognitive and social) with the mean between 3.70 and 3.964 . It was also noted that there were two categories (memory and affective) that were regarded as medium frequency of use ( 3.100 and 2.890). The most frequently used language learning strategies was metacognitive strategies (Mean=3.964), while affective strategies recorded to be the lowest mean scores (Mean=2.890).

\subsection{Individual Strategy Use}

The total means and the description of frequency use of each item were presented based on their categories. Generally, the statistics showed that a total of 33 out of 50 strategies recorded to be in the high level of use category (Mean=3.50 to 5.00). The 17 remaining items were recorded to be medium frequency of use.

\subsubsection{Memory}

Table 2. Mean Scores and Percentage of Memory Strategy

\begin{tabular}{lccccccc}
\hline \multicolumn{1}{c}{ Statement } & 1 & 2 & 3 & 4 & 5 & Mean & Frequency Level \\
\hline $\begin{array}{l}\text { I use new English words in a } \\
\text { sentence so I can remember } \\
\text { them. }\end{array}$ & - & - & 2 & 6 & 2 & 4.00 & High \\
\hline $\begin{array}{l}\text { I use flashcards to remember } \\
\text { new English words. }\end{array}$ & 6 & 2 & 2 & - & - & 1.60 & Medium \\
& $(60 \%)$ & $(20 \%)$ & $(20 \%)$ & & & & $(20 \%)$ \\
\hline
\end{tabular}

The mean scores indicated that four items were at high scale of frequency with mean scores ranging from 3.60 to 4.00 for these strategies. The item that revealed the highest mean score was "I use new English words in a sentence so I can remember them". Since the medium of instruction in the university was English, the students were to immerse themselves in using the language. Over the years of exposure in the target language, the students were able to develop familiarity with new English words and learned to use them in context. As proven by the result, they agreed that using new English words in a sentence can help to retain them. In contrast, the item that has the lowest mean score was "I use flashcards to remember new English words". According to Saeed Mojarradi (2014) in his article entitled "The effect of using flashcards on ESL students' ability to learn vocabulary', he discovered the use of flashcards did not have an effect on students' ability to learn vocabulary. Furthermore, a study conducted by Baleghizadeh and Ashoori (2011) also indicated there was no significant impact in the use of flashcards towards better learning strategy. The finding of the present study suggested flashcards were not favored as a learning strategy, hence supported the aforementioned literature reviews. Though flashcards might lead language learners to a higher level of vocabulary improvement as suggested by Komachali \& Khodareza (2012), it remained to be studied and proven in a more comprehensive study.

4.2.2 Cognitive

Table 3. Mean Scores and Percentage of Cognitive Strategy

\begin{tabular}{lccccccc}
\hline \multicolumn{1}{c}{ Statement } & 1 & 2 & 3 & 4 & 5 & Mean & Frequency Level \\
\hline $\begin{array}{l}\text { I watch English language } \\
\text { TV shows or go to movies } \\
\text { spoken in English. }\end{array}$ & - & - & - & - & 10 & 5.00 & High \\
\hline $\begin{array}{l}\text { I try to find patterns in } \\
\text { English }\end{array}$ & 1 & 3 & 3 & 2 & 1 & 2.50 & Medium \\
\end{tabular}

The mean scores designated that 11 items are at high scale of frequency with mean scores ranging from 3.50 to 5.00 for 
cognitive strategies. The item that indicated the highest mean score was "I watch English language TV shows or go to movies spoken in English", while the item that has the lowest mean score was "I try to find patterns in English". Many researchers discovered the used of movies in a classroom provided exposures to the real language and authentic settings in which the language is spoken (Xhemaili, 2013). They also found that movies hooked learners' interest and positively increase their motivation to learn English (Kusumarasdyati, 2004). The above findings were consistent and significantly relevant to the results of this study as all ten respondents reflected their opinions as 'strongly agreed' that they watched English language TV shows or go to movies spoken in English. This result could be supported by the fact that the respondents had easy and free access to internet connection. As the university provided round-the-clock internet connectivity on the campus and hostel areas, the students had an ideal opportunity to access online movie websites and managed to learn English language from the activity. On the contrary, finding patterns in English appeared to be a hindrance to the students for it might not relate to their needs and purpose in learning English.

\subsubsection{Compensatory}

Table 4. Mean Scores and Percentage of Compensatory Strategy

\begin{tabular}{lccccccc}
\hline \multicolumn{1}{c}{ Statement } & 1 & 2 & 3 & 4 & 5 & Mean & Frequency Level \\
\hline $\begin{array}{l}\text { If I can't think of an English } \\
\begin{array}{l}\text { word, I use a word or phrase } \\
\text { that means the same thing }\end{array}\end{array}$ & - & - & $\begin{array}{c}1 \\
(10 \%)\end{array}$ & $\begin{array}{c}2 \\
(20 \%)\end{array}$ & $\begin{array}{c}7 \\
(70 \%)\end{array}$ & 4.60 & High \\
\hline $\begin{array}{l}\text { I make up new words if I do } \\
\text { not know the right ones in }\end{array}$ & 2 & 2 & 1 & 3 & 2 & 3.10 & Medium \\
\begin{tabular}{l} 
English. \\
\hline
\end{tabular} & $(20 \%)$ & $(20 \%)$ & $(10 \%)$ & $(30 \%)$ & $(20 \%)$ & & \\
\hline
\end{tabular}

The mean scores specified that four items are at high scale of frequency with mean scores ranging from 3.50 to 4.60 for compensatory strategies. The highest mean score was "If I can't think of an English word, I use a word or phrase that means the same thing". Oxford (1990) stated that compensation strategies can be applied to overcome knowledge limitations in all four skills. The results suggested all respondents did utilize compensation learning strategy to tackle loopholes of their knowledge on the language, with seven of them interpreted their opinions as 'strongly agreed'. On the opposite, the lowest mean score was "I make up new words if I do not know the right ones in English". Six respondents were positive towards this strategy while another four respondents were negative. This was probably due to unfamiliarity to the technique which therefore led to minimum exploration.

\subsubsection{Metacognitive}

Table 5. Mean Scores and Percentage of Metacognitive Strategy

\begin{tabular}{lccccccc}
\hline \multicolumn{1}{c}{ Statement } & 1 & 2 & 3 & 4 & 5 & Mean & Frequency Level \\
\hline $\begin{array}{l}\text { I notice my English mistakes } \\
\text { and use that information to } \\
\text { help me do better. }\end{array}$ & - & - & 1 & 3 & 6 & 4.50 & High \\
\hline $\begin{array}{l}\text { I pay attention when } \\
\text { someone is speaking }\end{array}$ & - & - & 1 & 3 & 6 & 4.50 & High \\
$\begin{array}{l}\text { English. } \\
\text { I plan my schedule so I will } \\
\text { have enough time to study }\end{array}$ & $10 \%)$ & $(10 \%)$ & $(30 \%)$ & $(60 \%)$ & & Medium \\
English. & $(10 \%)$ & $(80 \%)$ & - & 1 & - & 2.10 & \\
\hline
\end{tabular}

The mean scores pointed out that eight items are at high scale of frequency with mean scores ranging from 3.80 to 4.50 . The items that exhibited the highest mean scores were "I notice my English mistakes and use that information to help me do better" and "I pay attention when someone is speaking English". Interestingly, the students designed and strategize learning process by noticing their own mistakes and paid attention when they listened to English-spoken conversations to help them become better at the language. The results suggested as students developed awareness on how they learn best, they will routine these strategies to efficiently obtain new information, and eventually became autonomous thinkers. Metacognitive strategy can positively impact students by helping them deepen their thinking about the content of the language. On the other hand, the item that has the lowest mean score was "I plan my schedule so I will have enough time to study English". Most of the respondents disagreed they scheduled and allocated specific time to study English. Presumably, they did not regard English learning as imperative as other major critical courses they enrolled and therefore, pay less focus to self-study the language. The respondents seemed to moderately delve deeper into the autonomous learning experience probably due to over-dependence on their lecturers to assign tasks and further facilitate language learning. Additionally, as English subjects were only offered in three semesters throughout the whole academic years, the students paid less attention to learn the language right after the completion of the formal classes. 


\subsubsection{Affective}

Table 6. Mean Scores and Percentage of Affective Strategy

\begin{tabular}{lccccccc}
\hline \multicolumn{1}{c}{ Statement } & 1 & 2 & 3 & 4 & 5 & Mean & Frequency Level \\
\hline $\begin{array}{l}\text { I encourage myself to speak } \\
\begin{array}{l}\text { English even when I am } \\
\text { afraid of making a mistake. }\end{array}\end{array}$ & - & 1 & - & 3 & 6 & 4.40 & High \\
\hline $\begin{array}{l}\text { I talk to someone else about } \\
\text { how I feel when I am } \\
\text { learning English. }\end{array}$ & $\begin{array}{c}(10 \%) \\
(40 \%)\end{array}$ & $\begin{array}{c}4 \\
(40 \%)\end{array}$ & $\begin{array}{c}(20 \%) \\
(60 \%)\end{array}$ & - & - & 1.80 & Medium \\
\hline
\end{tabular}

For affective strategies, the mean scores specified that two items are at high scale of frequency with mean scores ranging from 3.80 to 4.40. The item that displayed the highest mean score was "I encourage myself to speak English even when I am afraid of making a mistake", while the item that has the lowest mean score was "I talk to someone else about how I feel when I am learning English". Being ESL learners, they were required to use English as a mean to survive their education and communication in the university. Therefore, the tendency of using more affective strategies can be seen relatable to these ESL learners as they had intrinsic and extrinsic motivations to enhance their language proficiency and competency. Majority of the respondents reflected positively to the use of self-encouragement in speaking English even though they concerned about making mistakes. According to Oxford and Nyikos (1989), the degree of expressed motivation was the single most powerful influence on the choice of language learning strategies. Additionally, intrinsic motivation to communicate in the target language is likely to enhance a learner's learning experiences (Skehan, 2001). Besides, extrinsic motivation can also promote success in acquiring the target language (Gardner and MacIntyre, 1992). The findings in the present study supported the aforementioned statements and strengthened the fact that good language learners possessed an intrinsic motivation in learning a language. Adversely, most of the respondents were unwilling to talk about their feelings in regard to English language learning. The learners might refuse to confide in someone else about their thoughts and feelings as they doubted that might lead other unwanted issue such as low self-esteem.

4.2.6 Social

Table 7. Mean Scores and Percentage of Social Strategy

\begin{tabular}{|c|c|c|c|c|c|c|c|}
\hline Statement & 1 & 2 & 3 & 4 & 5 & Mean & Frequency Level \\
\hline $\begin{array}{l}\text { If I do not understand } \\
\text { something in English, I ask } \\
\text { the other person to slow } \\
\text { down or to say it again. }\end{array}$ & - & $\begin{array}{c}1 \\
(10 \%)\end{array}$ & $\begin{array}{c}2 \\
(20 \%)\end{array}$ & $\begin{array}{c}1 \\
(10 \%)\end{array}$ & $\begin{array}{c}6 \\
(60 \%)\end{array}$ & 4.20 & High \\
\hline $\begin{array}{l}\text { I ask English speakers to } \\
\text { correct me when I talk. }\end{array}$ & $\begin{array}{c}1 \\
(10 \%)\end{array}$ & $\begin{array}{c}2 \\
(20 \%)\end{array}$ & $\begin{array}{c}2 \\
(20 \%)\end{array}$ & $\begin{array}{c}3 \\
(30 \%)\end{array}$ & $\begin{array}{c}2 \\
(20 \%)\end{array}$ & 3.30 & Medium \\
\hline
\end{tabular}

The mean scores directed that four items are at high scale of frequency with mean scores ranging from 3.70 to 4.20 for these strategies. The item that presented the highest mean score was "If I do not understand something in English, I ask the other person to slow down or to say it again". Learning English in a supportive environment provides ESL learners with many interaction opportunities to practice the language. Asking for clarifications and repetitions as language learning strategies provided a meaningful learning experience to the students. Based on the results, good language learners sought opportunities to practice language and valued communication with other English speakers. As opposed to that, the item that has the lowest mean score was "I ask English speakers to correct me when I talk", as they might get offended and demoralized in the learning process. This particular result corresponded to the study conducted by Brown (2007), in which he asserted that good language learners learned the target language by assessing their own trails and errors.

\section{Discussion of findings}

The findings of the study revealed that good language learners were high users of language learning strategies. It supported the study carried out by Mohamed Amin Embi et al., (2001) in which he revealed good language learners possessed a greater use of language learning strategies compared to poor language learners. Likewise, ample past studies explored the relationship between language learning strategies and learners' proficiency in which the findings showed that more proficient language learners used a greater variety of language learning strategies (Rahimi et al., 2008; Griffiths, 2003; Lee, 2003; O’Malley and Chamot, 1990). The total means of each category showed that metacognitive strategies (Mean=3.964) are among the most frequently used strategies, followed respectively by compensatory (Mean=3.814), cognitive (Mean=3.812), social (Mean=3.700), memory (Mean=3.100) and affective strategies (Mean=2.890) found as the least used strategies among successful language learners. Based on the results, it was found that good language learners employed and favored more direct strategies (memory, cognitive and compensation) over indirect strategies (metacognitive, affective, and social). This can be inferred that successful language learners of the said university preferred to use strategies that are seen to have direct impact with the target language.

As Oxford (1990) stated, "all direct strategies require mental processing of the language". To better understand this 
system, memory strategies are the techniques used to collect and recover info, transform information in the form of facts to skills. A good example of this is grouping verbs into transitive or intransitive. Cognitive strategies are methods to operate the elements of language and students were able to make sense of their learning. An example of this type of strategy is contrastively analyzing words in mother tongue that have similarities with the words in the target language in terms of sound and meaning. Compensation strategies assist students to tackle loopholes of their prior knowledge in order to maintain conversation. For example, the students try to understand the target language by making clever guesses from the context. Through the use of linguistic clues for instance, a learner may be able to guess the topic of a conversation through the verbs used.

Furthermore, they are reported to possess a high frequency of use of metacognitive strategies which interestingly appeared to be the findings in other studies. Such results were said to be gathered in researches done by Haifa (2010), Adel (2011), as well as Jalal and Karev (2011). This result indicated that metacognitive strategies are mostly ideal for these successful students, as the learner autonomy exists for the learners to monitor and govern their own learning process. The findings revealed that the students coordinated their own learning by planning and organizing, as well as evaluating their learning process. The present findings were paralleled to the research done by Tricia Hedge (2000) which she identified seven characteristics of a good language learner. According to her, she believed good language learners in which she referred to as 'self-directed learners', were those who responsible for their own learning process, highly motivated, manage and divide time to learn properly, learn with active thinking, know their needs and to use resources independently. Moreover, Holden (2002) suggested that successful language learners were autonomous learners and both cognitively and meta-cognitively aware of their role in the learning process. Age factor could also be one of the reasons for the preference towards this strategy. As the respondents were university students which could be considered as adult learners, their language proficiency progress tremendously and their use of metacognitive strategies amplifies. In other words, they develop better learning skills as they grow older. However, the projection for future research should investigate the correlations between age and strategies employed by good language learners.

On the contrary, good language learners in this study were seen to use affective strategies the least. Affective strategies are the strategies to assist learners to manage their emotions, motivation, and attitudes towards learning. They can be achieved through lessening nervousness by using relaxation techniques, self-encouragement and self-reward in order to keep oneself motivated in the learning process, and taking emotional temperature into thoughtful considerations. Past research revealed that some ESL learners were susceptible to be affected by emotional issues such as anxiety, trauma and lack of confidence. Mayes (2003) found strong evidence to support that some ESL students experienced culture shock or trauma, and distressed by certain affective factors such as anxiety, lack of confidence and lack of motivation. The aforementioned finding by Mayes (2003) paralleled with the finding in this study as the learners experienced sensitivity to their emotional needs in the language learning process.

The findings also enlightened the fact that good language learners keen to use different strategies in combination. This result was well supported by the study carried out by Nambiar (1996) and Mah (1999) which they have found out Malaysian postgraduate students used the cognitive and metacognitive strategies in mixture. This significant finding is really a stepping stone for the language teachers or facilitators to better understand the reasons lie behind the learners' differences in the language learning strategy context. Furthermore, the training of language learning strategy can be implemented to poor language learner so that they can enjoy the chance to be at par with their counterparts, since effective and maximum usage of language learning strategies can lead them to learn the language better.

\section{Implications}

Since education is a creative industry, the knowledge of language learning strategies can significantly contribute to the enhancement of the teaching and learning process. Upcoming studies on language learning strategies could explore the new perspective in teaching approach, different variables exist and how these factors might boost or facilitate certain strategies while hindering others. Language instructors or lecturers could employ contexts of learning in order to help learners use a wider range of strategies and also discover new ones. To conclude, language learning strategies possess countless potential in enhancing language learning attainment. Students have to be exposed and taught to employ these strategies in their language learning journey. Lecturers might want to work to increase the awareness among their students on the strategies to equip and facilitate their students with meaningful language learning experiences. Additionally, lecturers should increase their awareness on affective factors that could greatly impact their students' motivation and attitude towards learning the language. By being more sensitive to the students' needs, lecturers could create inclusive learning environments to better serve their ESL students with supplementary needs and supports.

\section{References}

Adel, A. R. (2011). Effects of L2 proficiency and gender on choice of language learning strategies by university students majoring in English. Asian EFL Journal, 13(1), 115-151.

Bacon, S. M, and M. D. Finnemann (1990). A study of the attitudes, motives, and strategies of university foreign language students and their disposition to authentic oral and written input. Modern Language Journal, 74(4), 459470.

Baleghizadeh, S., \& Ashoori, A. (2011). The Impact of Two Instructional Techniques on EFL Learners' Vocabulary Knowledge: Flash Cards versus Word Lists. MEXTESOL Journal, 35(2). 
Chang, S. (1990). A study of the language learning behavior of Chinese students at the University of Georgia and the relation of those behaviors to oral proficiency and other factors. (Doctoral dissertation). University of Georgia.

Chamot, A. U., \& O’Malley, J. M. (1996). Implementing the cognitive academic language learning approach (CALLA). In R. L. Oxford (Ed.), Language learning strategies around the world: Cross-cultural perspectives (pp. 167-173). Honolulu: University of Hawaii, Manoa.

Chamot, A. U., Barnhardt, S., El-Dinary, P. B., \& Robbins, J. (1999). The learning strategies handbook. White Plains, NY: Addison Wesley Longman.

Cohen, A. D. (1996). Verbal reports as a source of insights into second language learner strategies. Applied Language Learning, 7(1-2), 5-24.

Cohen, A. D., Weaver, S. J., \& Li, T-Y. (1995). The impact of strategies-based instruction on speaking a foreign language. Research Report. Minneapolis, MN: University of Minnesota, Center for Advanced Research on Language Acquisition (CARLA).

Cook, V. (1991). Second Language Learning and Language Teaching. London: Edward Arnold.

Dornyei, Z. (1990). Conceptualizing motivation in foreign language learning. Language Learning, 40, 45-79.

Dornyei, Z. \& Skehan, P. (2003). Individual differences in second language learning. In C. Doughty \& M. Long (Eds), Handbook of Second Language Acquisition (pp. 589-630). Oxford: Blackwell.

Dreyer, C., \& Oxford, R. L. (1996). Learner variables related to ESL proficiency among African speakers in South Africa. In: R. L. Oxford (Ed.), Language learning strategies around the world: Cross-cultural perspectives (pp. 61-74). Honolulu: University of Hawaii, Manoa.

Ehrman, M. E., \& Oxford, R. L. (1989). Effects of sex differences, career choice, and psychological type on adult language learning strategies. The Modern Language Journal, 73, 1-12.

Ehrman, M. E., \& Oxford, R. L. (1990). Adult learning styles and strategies in an intensive training setting. The Modern Language Journal, 74, 311-26.

Ellis, R. (1994). The Study of Second Language Acquisition. Oxford: Oxford University Press.

Ellis, H. D., \& Sinclair, B. (1989). Learning to learn English: A course in learner training. Cambridge, UK: Cambridge University Press.

Embi, M. A. (2000). Language Learning Strategies: A Malaysian Context. Bangi: Percetakan Warni.

Embi, M. A., Long, J. \& Hamzah, M. I. (2001). Language Learning Strategies Employed by Secondary School Students in Malaysia. Jurnal Pendidikan, 26, 2-3.

Gardner, R. and MacIntyre, P. (1992). An Instrumental Motivation in Language Study: Who says it isn't effective? Studies in Second Language Acquisition, 13, 57-72.

Green, J. (1991). Language learning strategies of Puerto Rican university students. Paper presented at the annual meeting of the Puerto Rican Teachers of English to Speakers of Other Languages, San Juan, PR.

Griffiths, C. (2003). Patterns of language learning strategy use. System, 31, 367-383.

Haifa, A. B. (2010). Language Learning Strategies Employed by English Majors at Qatar University: Questions and Queries. ASIATIC, 4(2).

Harris, V. (2000). Learning to learn: Strategy instruction in the modern language classroom. In A. Schwarbick (Ed.), Aspects of teaching second modern foreign languages: Perspectives on practice (pp. 3-22). London/New York: Routledge/Falmer.

Harris, V. (2001). Helping learners learn: Exploring strategy instruction in language classrooms across Europe. Strasbourg, France: Council of Europe Publishing.

Hedge, T. (2000). Teaching and Learning in the Language Classroom. Oxford: Oxford University Press.

Holden, B. (2002). Listen and Learn. English Teaching Professional, 23, 18-20.

Jalal, K., \& Karev, J. (2011). The strategy use frequency of unsuccessful Malaysian language learners and the effect of gender on it. European Journal of Scientific Research, 57(2), 198-205.

Kaylani, C. (1996). The influence of gender and motivation on EFL learning strategy use in Jordan. In R. L. Oxford (Ed.), Language learning strategies around the world: Cross-cultural perspectives (pp. 75-88). Honolulu: University of Hawaii, Manoa.

Khodareza \& Komachali, E. (2012). The Effect of Using Vocabulary Flashcard on Iranian on Iranian PreUniversity Students' Vocabulary Knowledge. Canadian Center of Science and Education Journal, 5(3), $134-147$.

Krashen, S. (1981). Second language acquisition and second language learning. Oxford: Pergamon Press.

Kusumarasdyati (2004). Listening, Viewing and Imagination: Films in EFL Classes. $2^{\text {nd }}$ International Conference on Imagination and Education, Vancouver, Canada.

Lee, K. (2003). The relationship of school year, sex and proficiency on the use of learning strategies in learning English. Asian EFL Journal, 5(4), 1-36. 
Mah, S. F. (1999). The language learning strategies of Malaysian undergraduates from national primary schools and national type (Chinese) primary schools for completing selected ESL classroom activities. (Unpublished master's thesis). Universiti Kebangsaan Malaysia, Bangi, Malaysia.

Mayes, E. (2003). When ESL is not enough. In Identification, Assessment and Programming for ESL Learners with Special/Additional Needs: Five Case Studies. BCTF Research, 141-161.

Mendelsohn, D. (1994). Learning to listen: A strategy-based approach for the second-language learner. San Diego, CA: Dominie Press.

Mojarradi, S. (2014). The effect of using flashcards on ESL (English as a Second Language) students' ability to learn vocabulary. International Journal of Scientific World, 2(2), 56-61.

Naiman, N., Frohlich, M., Stern, H. H., \& Todesco, A. (1978). The good language learner. Toronto, Ontario, Canada: Ontario Institute for Studies in Education.

Nambiar, R. (1996). Language learning strategies of six Malaysian ESL learners when performing selected language activities. (Unpublished master's thesis). Universiti Kebangsaan Malaysia, Bangi, Malaysia.

O’Malley, J. M., \& Chamot, A. U. (1990). Learning strategies in second language acquisition. Cambridge, UK: Cambridge University Press.

O'Malley, J. M., Chamot, A., Stewner-Manzanares, G., Kupper, L. \& Russo, R. (1985). Learning strategies used by beginning and intermediate ESL students. Language Learning, 35(1), 21-46.

Oxford, R. L. (1990). Language learning strategies: What every teacher should know. New York: Newbury House HarperCollins.

Oxford, R. L. (1992). The story of the SILL: Evaluation, use, reliability, and validity of the Strategy Inventory for Language Learning around the world. Tuscaloosa, AL: University of Alabama.

Oxford, R. L. (1993). Instructional implications of gender differences in second/foreign language (L2) learning styles and strategies. Applied Language Learning, 4, 65-94.

Oxford, R. L. (Ed.) (1996). Language learning strategies around the world: Cross-cultural perspectives. Honolulu: University of Hawaii, Manoa.

Oxford, R. L., \& Cohen, A. D. (1992). Language learning strategies: Crucial issues of concepts and classification. Applied Language Learning, 3(1-2), 1-35.

Oxford, R. L., \& Ehrman, M. E. (1995). Adults' language learning strategies in an intensive foreign language program in the United States. System, 23(3), 359-356.

Oxford, R. L., \& Nyikos, M. (1989). Variables affecting choice of language learning strategies: A synthesis of studies with implications for strategy training. System, 17, 235-247.

Oxford, R. L., Nyikos, M., \& Ehrman, M. (1988). Vive la difference? Reflections on sex differences in use of language learning strategies. Foreign Language Annals, 21(4), 321-329.

Rahimi, M., Riazi, A., \& Saif S. (2008). An investigation into the factors affecting the use of language learning strategies by Persian EFL learners. CJAL, 11(2): 31-60.

Rubin, J. (1975). What the 'good language learner' can teach us. TESOL Quarterly, 9(1), 41-51.

Rubin, J., \& Thompson, I. (1994). How to be a more successful learner (2nd ed.). Boston: Heinle \& Heinle.

Rubin, J. (1981). Study of cognitive processes in second language learning. Applied Linguistics, 2(2), $117-131$.

Skehan, P. (2001). Comprehension and production strategies in language learning. London, Routledge.

Stern, H. H. (1975). What can we learn from the good language learner? Canadian Modern Language Review, 31(3), 304-317.

Touba, N. (1992). Language learning strategies of Egyptian student teachers of English. Paper presented at the 12th National Symposium on English Teaching in Egypt, Nasr City, Cairo, Egypt.

Watanabe, Y. (1990). External variables affecting language learning strategies of Japanese EFL learners: Effects of entrance examination, years spent at college/university and staying overseas. (Unpublished master's thesis). Lancaster University, Lancaster, UK.

Wenden, A. and Rubin, J. (Eds) (1987). Learner Strategies in Language Learning. Englewood Cliffs, N.J., Prentice Hall.

Weinstein, C. E., \& Rogers, B. T. (1984). Comprehension monitoring: The neglected learning strategy. Paper presented at the annual meeting of the American Educational Research Association, New Orleans, LA.

Xhemaili, Mirvan (2013). The advantages of using films to enhance student's reading skills in the EFL classroom. Journal of Education and Practice, 4(13).

Yunus, M. M., Sulaiman, N. A., Embi, M. A. (2013). Malaysian gifted students' use of English language learning strategies. English Language Teaching, 6(4). 